\title{
DICTYOTA ADNATA ZANARDINI (PHAEOPHYCEAE) - A NEW RECORD FROM THE SUNDARBANS MANGROVE FORESTS, BANGLADESH
}

\author{
Md Ariful Islam, Md Rashedul Islam¹, Abdul Aziz ${ }^{2}$ and Lawrence M Liao* \\ Aquatic Botany Laboratory, Department of Bioresource Science, Graduate School of Biosphere \\ Science, Hiroshima University, Higashi-Hiroshima, Japan 739-8528
}

Keywords: Brown algae, Epiphyte, Phycology, Taxonomy, A new record

\begin{abstract}
Samples were collected from Arpangasia and Kholpetua rivers within the Sundarbans in Bangladesh during February to March and December 2018. Among several forms was found a tightly prostrate brown alga occurring on moist parts of mangrove plants and clayey soil. Flattened brownish thalli tightly attached to pneumatophores and lower parts of mangrove trunks, spreading and branching dichotomously, sometimes overlapping and attached by means of unbranched marginal and sub-marginal rhizoids were collected. Distinct marginal sori are well developed in fertile specimens. On the basis of these characters, the sample has been identified as Dictyota adnata Zanardini which is herein reported as a new record for Bangladesh.
\end{abstract}

The Sundarbans is the world's largest mangrove ecosystem that is shared by India and Bangladesh fronting the vast Bay of Bengal to the south representing a unique ecosystem showcasing an astounding floral and faunal assemblage that is constantly exposed to various anthropogenic and natural threats (Aziz and Paul 2015). The rich biodiversity and largest contiguous forests of the Sundarbans were recognized when large portions of it were designated as a UNESCO World Heritage Site as well as a Ramsar site. The algal flora within the Sundarbans was first studied by Islam (1973) who documented 35 species, most of them belonging to the "Bostrychietum" group. Only one brown algal species was recorded in that study, the ubiquitous Colpomenia sinuosa (Mertens ex Roth) Derbès \& Solier, which was also encountered in this study growing on the muddy river banks.

This report deals with the discovery of an apparently uncommon species of brown alga that is different from its congeners in many aspects. Dictyota adnata Zanardini is a member of a genus that is commonly found in most tropical and subtropical coral reef habitats occurring in truly marine conditions (>32 ppt salinity). This species is perhaps the only member of Dictyota that occurs in estuarine conditions and is herein reported from the mangrove forests of Bangladesh for the first time, and likewise a new addition to the algal flora of Bangladesh.

Specimens were collected during the low tide from the mangrove stands along the banks of the Arpangasia river $\left(22^{\circ} 9^{\prime} 9.53^{\prime \prime} \mathrm{N}\right.$ and $\left.89^{\circ} 16^{\prime} 34.84^{\prime \prime} \mathrm{E}\right)$, the Kholpetua River $\left(22^{\circ} 16^{\prime} 7.77^{\prime \prime} \mathrm{N}\right.$ and $89^{\circ} 14^{\prime} 58.70^{\prime \prime}$ E) and nearby areas within the Sundarbans mangrove forest, Bangladesh in February and March, and December 2018. Samples were collected by scraping mangrove trunks and pneumatophores with a small knife and field-preserving in ethanol and by air drying for carrying to the Aquatic Botany Laboratory, Graduate School of Biosphere Science, Hiroshima University, Japan. In the first sampling only 10 specimens were collected, however in second sampling around 200 specimens were collected with revisiting the same sampling stations. For proper identification the distinct features of external and internal morphologies of both vegetative

*Author for correspondence: <lliao@hiroshima-u.ac.jp>. ${ }^{1}$ Fisheries \& Marine Resource Technology Discipline, Khulna University, Khulna 9208, Bangladesh. ${ }^{2}$ Department of Botany, University of Dhaka, Dhaka-1000, Bangladesh. 
and reproductive structures were used and compared with descriptions in the literature. Hand sections using double-edged razor blades were mounted without staining and examined by stereo dissecting and compound light microscopes (Nikon SMZ1500 and Nikon ECLIPSE E400) and pictures were taken by a digital camera mounted on the microscope (Nikon DS-Fi1 and Inohara INOCAM-30U2CM). A total of 20 examined specimens were collected from both seasons to confirm the identity of the species $D$. adnata. Voucher specimens are yet to be deposited in the Bangladesh National Herbarium, Dhaka.

Dictyota adnata Zanardini 1878: 34.

(Figs 1-12)

Type locality: Originally collected by Oeduardo Beccari from Irian Jaya, western New Guinea, now part of Indonesia and described by Zanardini (1878) and later neotypified by De Clerck and Coppejans (1997) using a sample from Kei Archipelago (Kepulauan Kei), also in Indonesia and which was collected by Anna Weber-van Bosse.

Specimens examined: Arpangasia river (AHC 001), Kholpetua river (AHC 001-002), 2627/02/2018; Kolagachia river (AHC 111-113), 04-05/12/2018.

References: De Clerck 2003: 32-36, figs. 7A-F, 8A-E; Kyaw \& Soe-Htun 2012: 6, figs. 2-9; Coppejans 1990: 373, figs. 1-15.

Fronds are yellowish or dark brown in colour and prostrate on mangrove trunks and pneumatophores, sub-dichotomously branched with $65-100^{\circ}$ angle (Figs $1-3$ ). Thallus is around $3.0-4.5 \mathrm{~cm}$ long and about $2.5-4.0 \mathrm{~cm}$ high. The length of interdichotomics is shorter $(2.5-3.0$ $\mathrm{mm}$ ) and the average blades width is $0.8-2.5 \mathrm{~mm}$. Internodal segments are $0.16-1.0 \mathrm{~cm}$ long (the lower value for proximal and higher value for distal ones) and $1.0-2.5 \mathrm{~mm}$ broad, smaller value is again for proximal portions). Rhizoidal filaments unbranched, occurring largely from the undersurface margins (both marginal and sub-marginal) of the thallus for secondary attachment (Fig. 4). The thallus consists of three layers (Figs 11, 12, ): the upper and lower epidermal layers of small, rectangular cells with one to three chromatophores, and the central medulla, composed of large, rectangular cells with/without chromatophores. The plants from mangroves along Arpangasia river do not contain chromatophores (Fig. 11) but some samples (AHC002) from Kholpetua river possess chromatophores (Fig. 12, indicated with asterisks) in the medulla. However, these might be artifacts of the sectioning process. In general medulla cells contain fewer plastids than the epidermis because of the cell position.

Tetrasporangia are formed singly or in groups from the upper marginal cells and attached by stalk cells (Figs 9, 10), sub-spherical to pear-shaped, 45 - $95 \mu \mathrm{m}$ long, $30-65 \mu \mathrm{m}$ broad, surrounded by an indusium.

Distribution: (Data mainly from Guiry and Guiry 2018): Atlantic Islands: Azores; Central America: Costa Rica; South America: Venezuela; Africa: Kenya, Tanzania; Asia: Vietnam, Indonesia, Myanmar, Malaysia, Singapore; Australasia: Queensland, Papua New Guinea, New Zealand; Pacific Islands: American Samoa, Central Polynesia, Federated States of Micronesia, Fiji, Tonga, New Caledonia.

Dictyota adnata was originally described by Zanardini (1878: 34-35) who examined samples from Irian Jaya (Western New Guinea) in Indonesia and who first noted the distinctive features such as the smaller thallus, the prostrate growth form and the marginal group of spores. In the study area, the species grows on tree trunks, on rocks and rarely on the ground/substrate in the upper parts of the intertidal zone, usually covered by a thin film of mud making them inconspicuous to the inexperienced collector. This muddy layer can significantly block sunlight potentially causing reduced photosynthesis and possibly also nutrient exchange. On the other hand, it could also play a role in reducing water loss and desiccation stress although there are no 


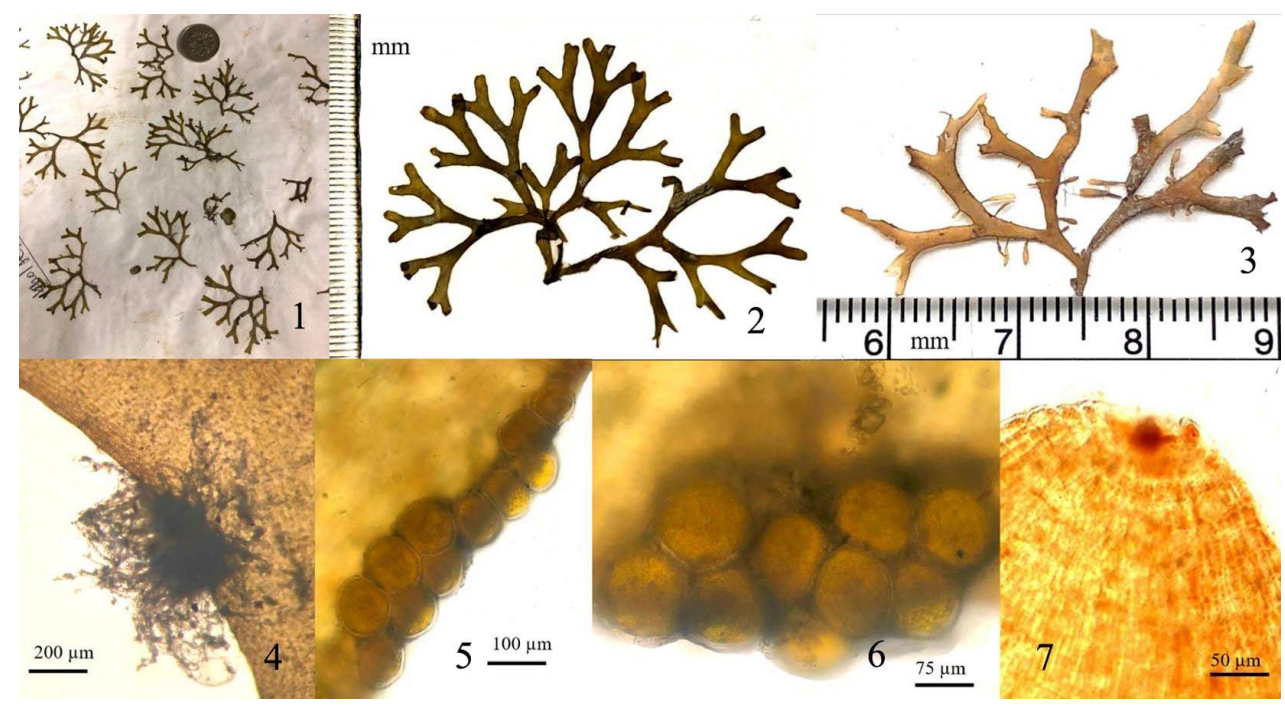

Figs 1-7. Dictyota adnata: 1. Several specimens on the herbarium sheet. 2. Close-up of a typical pressed plant sample (AHC 111). 3. Habit of pressed specimen (AHC 002) showing proliferations issued from the margins of the basal portions of the plant. These are likely in situ germinated spores still attached on the original thallus. 4. Cluster of rhizoidal filaments issued from the thallus margin. 5, 6. Clusters of marginal tetrasporangia. 7. Parenchymatous apical region showing a single, densely pigmented apical cell.

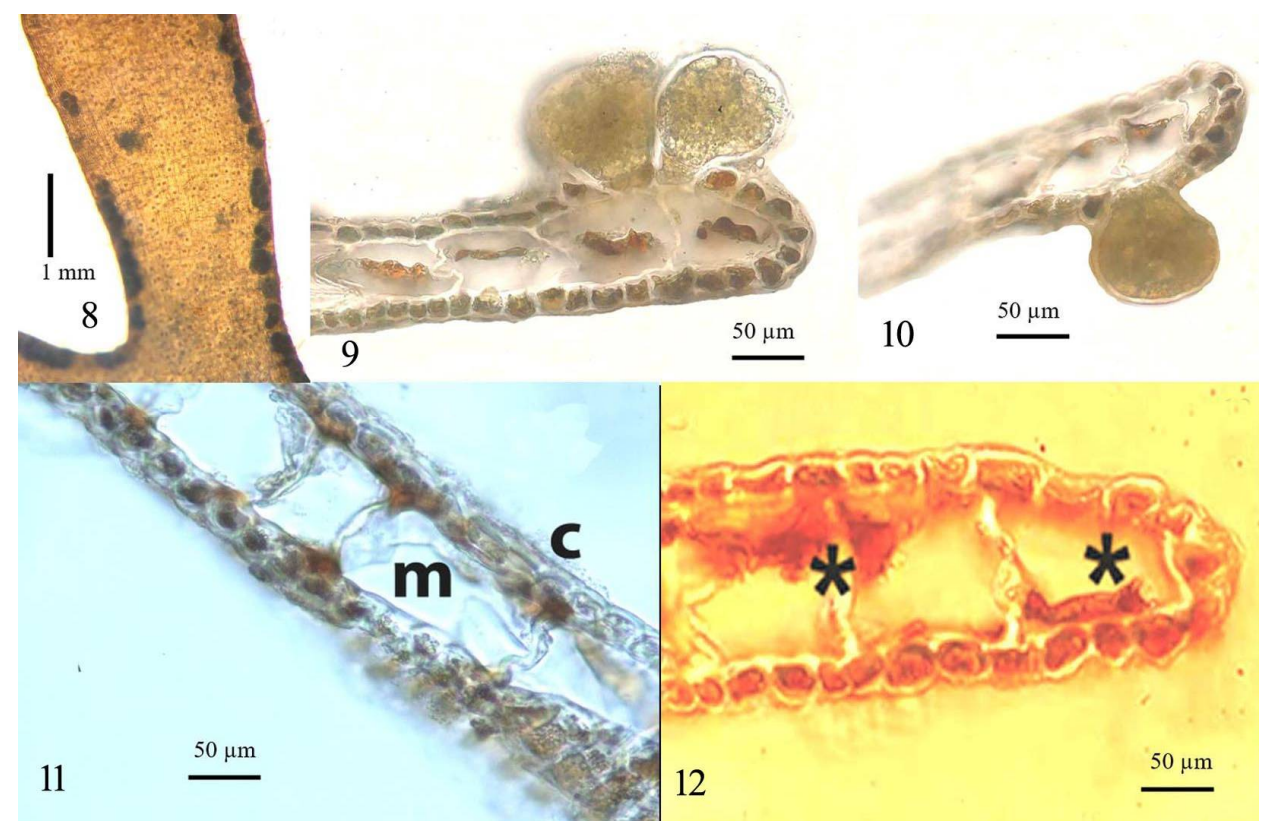

Figs 8-12. Dictyota adnata: 8. Rows of tetrasporangia arranged on both margins of the thallus. 9. X-S of thallus margin showing two tetrasporangia attached to the cortical layer by stalk cells. 10. X-S of thallus margin showing a tetrasporangium on the ventral margin. 11. X-S of thallus showing pigmented upper and lower cortical layers (c) and a single layered largely unpigmented medulla $(\mathrm{m}) .12 . \mathrm{X}-\mathrm{S}$ of thallus showing chromatophores (asterisks) within the medullary cells. 
Table 1. A morphometric comparison between the Dictyota species recorded from Bangladesh coast.

\begin{tabular}{|c|c|c|c|c|c|c|c|}
\hline Characters & D. adnata & D. bartayresiana & D. ciliotata & D. dichotoma & D. friabilis & D. hauckiana & D. implexa \\
\hline $\begin{array}{l}\text { Habit of } \\
\text { thallus }\end{array}$ & Prostrate & Prostrate & Erect & Erect & Procumbent & Erect & Erect \\
\hline $\begin{array}{l}\text { Colour of } \\
\text { thallus }\end{array}$ & $\begin{array}{l}\text { Yellowish to } \\
\text { dark brown }\end{array}$ & Yellow-brown & Dark brown & $\begin{array}{l}\text { Yellowish } \\
\text { brown }\end{array}$ & $\begin{array}{l}\text { Pale brown } \\
\text { to purplish }\end{array}$ & $\begin{array}{l}\text { Dark to golden } \\
\text { brown }\end{array}$ & Light brown \\
\hline $\begin{array}{l}\text { Thallus } \\
\text { height }(\mathrm{cm})\end{array}$ & $3-4.5$ & $3.5-20$ & $4.5-20$ & $3-18$ & $3-5$ & $5-75$ & $3-10$ \\
\hline $\begin{array}{l}\text { blades width } \\
(\mathrm{mm})\end{array}$ & $0.8-2.5$ & $3.3-3.9$ & $3.8-5.1$ & $3.2-7.3$ & $2.3-4.0$ & $28.8-38.5$ & $0.8-1.5$ \\
\hline $\begin{array}{l}\text { Branching } \\
\text { patterns }\end{array}$ & $\begin{array}{l}\text { DSubdichoto } \\
\text {-mous }\end{array}$ & $\begin{array}{l}\text { Repeatedly } \\
\text { dichotomous }\end{array}$ & $\begin{array}{l}\text { Isotomous } \\
\text { dichotomous }\end{array}$ & Dichotomous & $\begin{array}{l}\text { Isotomous to } \\
\text { anisoto- } \\
\text { mous dicho- } \\
\text { tomous or } \\
\text { irregular }\end{array}$ & Dichotomous & $\begin{array}{l}\text { Dichoto- } \\
\text { mous }\end{array}$ \\
\hline $\begin{array}{l}\text { Interdicho- } \\
\text { tomics } \\
\text { (length } \\
(\mathrm{mm})\end{array}$ & $2.5-3.0$ & $5.3-7.4$ & $11.3-28.5$ & $7.5-8.5$ & $4.1-5.0$ & $120.7-180.6$ & $8.0-8.7$ \\
\hline $\begin{array}{l}\text { Thallus } \\
\text { margin }\end{array}$ & Smooth & Smooth & $\begin{array}{l}\text { Smooth or } \\
\text { sparsely } \\
\text { dentate }\end{array}$ & Smooth & $\begin{array}{l}\text { Entirely } \\
\text { smooth }\end{array}$ & Undulate & Smooth \\
\hline $\begin{array}{l}\text { Marginal } \\
\text { proliferation }\end{array}$ & Fcrequent & Present & Frequent & Unknown & Present & Present & Unknown \\
\hline $\begin{array}{l}\text { Thallus } \\
\text { surface }\end{array}$ & Smooth & Smooth & $\begin{array}{l}\text { Smooth, } \\
\text { Sometimes } \\
\text { leaf-like } \\
\text { proliferations }\end{array}$ & $\begin{array}{l}\text { Smooth, } \\
\text { Occasionally } \\
\text { basal } \\
\text { proliferations }\end{array}$ & $\begin{array}{l}\text { Entirely } \\
\text { Smooth }\end{array}$ & Smooth & Smooth \\
\hline Rhizoids & $\begin{array}{l}\text { Margin form } \\
\text { bubndles, } \\
\text { basal }\end{array}$ & $\begin{array}{l}\text { Scattered at } \\
\text { margin, basal }\end{array}$ & Basal & Basal & $\begin{array}{l}\text { Marginal } \\
\text { form } \\
\text { bundles, } \\
\text { basal }\end{array}$ & Basal & Basal \\
\hline $\begin{array}{l}\text { Tetraspores } \\
\text { position }\end{array}$ & $\begin{array}{l}\text { Always } \\
\text { Marginal }\end{array}$ & Unknown & Surface & $\begin{array}{l}\text { Peripheral } \\
\text { cells, surface }\end{array}$ & Surface & Peripheral cells & Unknown \\
\hline $\begin{array}{l}\text { Apices } \\
\text { shape }\end{array}$ & $\begin{array}{l}\text { Rounded, } \\
\text { truncate, } \\
\text { acute }\end{array}$ & Rounded & Rounded & $\begin{array}{l}\text { Round, obtuse, } \\
\text { acute }\end{array}$ & $\begin{array}{l}\text { Rounded, } \\
\text { obtuse or } \\
\text { truncate }\end{array}$ & $\begin{array}{l}\text { Elongate, } \\
\text { obtuse }\end{array}$ & Rounded \\
\hline Iridescence & Absent & $\begin{array}{l}\text { Absent, blue, } \\
\text { green }\end{array}$ & $\begin{array}{l}\text { Absent, } \\
\text { yellow- } \\
\text { greenish }\end{array}$ & Blue-green & $\begin{array}{l}\text { Bluish, often } \\
\text { in broad } \\
\text { bands }\end{array}$ & Absent & $\begin{array}{l}\text { Green- } \\
\text { yellow light }\end{array}$ \\
\hline $\begin{array}{l}\text { Branching } \\
\text { angle }\left(^{\circ}\right)\end{array}$ & $65-100$ & $60-70$ & $40-80$ & $58-61$ & $70-80$ & unknown & $42-49$ \\
\hline References & $\begin{array}{l}\text { Present } \\
\text { work, } \\
\text { Coppejans } \\
\text { 1990, De } \\
\text { Clerck 2003, } \\
\text { Kyaw and } \\
\text { Soe-Htun } \\
2012\end{array}$ & $\begin{array}{l}\text { Islam 1976, } \\
\text { Darakrai 2012, } \\
\text { Lozano-Orozco } \\
\text { et al. } 2015\end{array}$ & $\begin{array}{l}\text { De Clerck and } \\
\text { Coppejans } \\
\text { 1999, Abbas } \\
2010 \text {, } \\
\text { Darakrai } \\
2012, \text { Lozano- } \\
\text { Orozco et al. } \\
2015\end{array}$ & $\begin{array}{l}\text { Islam 1976, } \\
\text { Abbas 2010, } \\
\text { Tronholm et al. } \\
2010,\end{array}$ & $\begin{array}{l}\text { Islam 1976, } \\
\text { De Clerck } \\
\text { and } \\
\text { Coppejans } \\
1999 \\
\text { Darakrai } \\
2012\end{array}$ & $\begin{array}{l}\text { De Clerck and } \\
\text { Coppejans } \\
\text { 1999, Abbas } \\
2010 \text {, }\end{array}$ & $\begin{array}{l}\text { Islam } 1976, \\
\text { Abbas } 2010, \\
\text { Tronholm } \\
\text { et al. } 2010\end{array}$ \\
\hline
\end{tabular}

experimental data to support this assumption. In neighboring Myanmar, Kyaw and Soe-Htun (2012) also observed the marginal position of tetrasporangia, and vegetative features such as the epidermis and hypodermis and the large-celled medulla. The plants were found in the upper intertidal zone of river mouths, on the pneumatophores and trunks of mangrove plants in the Bay 
of Bengal, quite similar to the present observations. Sundarbans material perfectly agreed with these descriptions and the environmental conditions observed there. Due to its unique habit, it is one of the easiest species to identify (De Clerck 2003). This species is likely widely distributed throughout the tropical regions as listed above but its muddy coating and tightly appressed habit may have rendered it inconspicuous to most collectors. Furthermore, there has been some confusion with the application of correct names to this species, a complicated nomenclatural issue addressed and resolved by Silva et al. (1996: 927-928). At least three species of Dictyota have now been relegated to the synonymy under D. adnata (De Clerck 2003, Guiry and Guiry 2018), namely $D$. sibogae Weber-van Bosse (an invalid name based on materials from Indonesia), $D$. submaritima Tanaka and Pham Hoang-Ho (type from Saigon River in Ho Chi-Minh City, Vietnam), and D. marginispora Coppejans (an invalid name based on materials from Kenya).

In Bangladesh, only six species of Dictyota [D. hauckiana Nizamuddin (recorded as $D$. atomaria Hauck), D. bartayresiana Lamouroux, D. ciliotata Sonder, D. dichotoma (Hudson) J.V. Lamouroux, Dictyota implexa (Desfontaines) J.V. Lamouroux (recorded as D. divaricata Lamouroux) and D. friabilis Setchell] were reported from St. Martin's Island and Cox's Bazaar district in southeastern Bangladesh (Islam 1976, Islam et al. 2004). Among all the species recorded from the Bangladesh coast they can be distinguished by their anatomic and reproductive traits such as in $D$. adnata and the type species $D$. dichotoma whose colour and branching pattern sometimes show resemblance (Table: 1). In addition it is difficult to separate by thallus height when they are young. However, the comparative examination of the thallus width, length of interdichotomies, rhizoidal arrangements, branching angles can help to distinguish species (Table 1). D bartayresiana, D. ciliotata, D. friabilis and D. hauckiana and D. implexa are far different in morphology from D. adnata (Table 1).

In view of the recent monographic work on Indian Ocean species of Dictyota by De Clerck (2003) and the rapid progress in molecular systematics work on the family Dictyotaceae (De Clerck et al. 2006), it is very important to re-examine previous records of Dictyota from Bangladesh. Without any doubt, D. adnata is herein reported for the first time from the Sundarbans mangrove forest and is added to the algal flora of Bangladesh.

\section{Acknowledgements}

Microphotographic equipment was kindly provided by Dr. Koichiro Kawai and Mr. Shaharior Arnob (Graduate School of Biosphere Science, Hiroshima University). Field work in Bangladesh was supported by a travel grant from the Graduate School of Biosphere Science as well as the issuance of a permit from the Bangladesh Forests Department. Valuable field assistance was provided by Mr Chayan Biswas (Khulna University). Postgraduate research of the first author (MAI) is made possible by a grant from the Monbukagakusho [MEXT - Japan Ministry of Education, Culture, Sports, Science and Technology].

\section{References}

Abbas A. 2010. Anatomical studies on the Phaeophycota of Karachi Coast, Ph.D. Thesis, Federal Urdu University of Arts, Science \& Technology, Karachi.

Aziz A and Paul AR 2015. Bangladesh Sundarbans: Present status of the environment and biota. Diversity 7 : 242-269.

Coppejans E 1990. Dictyota adnata Zanardini (Phaeophyta, Dictyotales) a remarkable mangrove inhabiting species in Kenya. Bull. Nat. Plantentuin Belg. 60: 371-380.

De Clerck O and Coppejans E. 1999. Two new species of Dictyota (Dictyotales, Phaeophyta) from the IndoMalayan region, Phycologia, 38 (3): 184-194. 
Darakrai A. 2012. Diversity, species composition and habitat of the genus Dictyota J.V. Lamour. and Canistrocarpus De Paula \& De Clerck in the Peninsular Thailand, Master's Thesis. Prince of Songkla University, Thailand.

De Clerck O 2003. The genus Dictyota in the Indian Ocean. Opera Bot. Belg. 13: 1-205.

De Clerck O and Coppejans E. 1997. The genus Dictyota (Dictyotaceae, Phaeophyta) from Indonesia in the herbarium Weber-van Bosse, including the description of Dictyota canaliculata spec. nov. Blumea 42 : 407-420.

De Clerck O, Leliaert F, Verbruggen H, Lane CE, De Paula JC, Payo DA and Coppejans E 2006. A revised classification of the Dictyoteae (Dictyotales, Phaeophyceae) based on $r b c \mathrm{~L}$ and 26S ribosomal DNA sequence analyses. J. Phycol. 42: 1271-1288.

Guiry MD and Guiry GM 2018. AlgaeBase. World-wide electronic publication, National University of Ireland, Galway. http://www.algaebase.org

Islam AKMN 1973. The algal flora of Sundarbans mangrove forest, Bangladesh. Bangladesh J. Bot. 2: 411436.

Islam AKMN 1976. Contribution to the study of the marine algae of Bangladesh. Bibl. Phycol. 19: 1-253.

Islam AKMN, Aziz A and Parvin R 2004. Marine algae of St. Martin's Island, Bangladesh- II. Brown algae. Bangladesh J. Plant Taxon. 11: 1-7.

Kyaw SPP and Soe-Htun U 2012. Systematics of Dictyota adnata Zanardini (Dictyotales, Phaeophyta) from Myanmar, Univ. Res. J. 5: 1-15.

Lozano-Orozco JG, Sentíes A, De Clerck O, Dreckmann KM and Díaz-Larrea J. 2015. Two new species of the genus Dictyota (Phaeophyceae: Dictyotales) from the Mexican Caribbean., Amer. J. Plant Sci. 6: 2492-2501.

Silva PC, Basson PW and Moe RL 1996. Catalogue of the benthic marine algae of the Indian Ocean. Univ. Calif. Publ. Bot. 79: 1-1259.

Tronholm A, Steen F, Tyberghein L, Leliaert F, Verbruggen H, Siguan MAR and De Clerck O. 2010. Species delimitation, taxonomy, and biogeography of Dictyota in Europe (Dictyotales, Phaeophyceae), J. Phycol. 46: 1301-1321.

Zanardini G. 1878. Phyceae papuanae novae vel minus cognitae a cl. O. Beccari in itinere ad Novam Guineam annis 1872-75 collectae. Nuovo Gior. Bot. Ital. 10: 34-40.

(Manuscript received on 19 March, 2019; revised on 23 September, 2019) 